\title{
Genetic Diversity Analysis of Sugarcane (Saccharum spp. Complex) based on Morphological Characterization Using Mahalanobis D $^{2}$
}

\author{
Neetu*, Anand Singh Jeena, Anil Kumar Bairwa, Deepak Koujalagi, \\ Surendra Pal Singh and Usha Pant
}

\author{
Department of Genetics and Plant Breeding, G.B. Pant University of Agriculture and \\ Technology, Pantnagar-263145 (Uttarakhand), India \\ *Corresponding author
}

\begin{tabular}{|l|}
\hline Ke y w o r d s \\
Sugarcane, \\
$\begin{array}{l}\text { Saccharum spp. } \\
\text { Mahalanobis } \mathrm{D}_{2}\end{array}$ \\
\hline Article Info \\
\hline $\begin{array}{l}\text { Accepted: } \\
\text { 26 July } 2018 \\
\text { Available Online: } \\
\text { 10 August } 2018\end{array}$ \\
\hline
\end{tabular}

A B S T R A C T

Cultivated sugarcane (Saccharum spp. complex, $2 \mathrm{n}=80$-120) belongs to the genus Saccharum of the family Poaceae. Sugarcane (Saccharum spp. complex) is an important cash crop of the tropical and subtropical regions of the world for its distinct characteristic of high sugar concentration accumulated in the stalk. Genetic diversity gives species the ability to adapt to changing environments, including new pests and diseases and new climatic conditions. In order to obtain the wide spectrum of variation among the segregants the genotypes belonging to the distant clusters, 36 genotypes of Sugarcane were subjected to detailed investigation for the underlined objectives to estimate the extent of genetic diversity among early generation clones of sugarcane based on morphological characterization and to identify donors from diverse group for yield and quality parameters. The analyses of variance revealed highly significant variation among the clones for all the characters studied such as NMC, cane height, cane thickness, single cane weight, juice brix $\%$, juice sucrose \%, juice purity \%, CCS \%, Cane yield and CCS yield. Based on D2 values, clustering of the 36 genotypes were carried out which resulted in ten diverse clusters. Cluster I was found to be the largest with 18 genotypes followed by Cluster III with four clones. Cluster II and Cluster IV were comprised of three clones each. Two genotypes each constituted Cluster V and Cluster VI. Rest of the clusters consisted of one genotype each. The clustering of clones could be utilized for identification of diverse parents for crossing programme to get maximum recombination which may generate high variability for various traits of interest. Clustering pattern and genetic diversity analysis gives an idea for developing the diverse genetic base for successful sugarcane breeding programme for improvement in the cane yield and quality characters. PC (2011-12)-579, PC (201112)-581 were superior for many cane yield and quality contributing characters viz. cane height $(\mathrm{m})$, juice brix percent, juice sucrose percent, juice purity percent, ccs percent and ccs yield $(\mathrm{t} / \mathrm{ha})$. Clones PC(2011-12)-561, PC(2011-12)-562, PC (2011-12)-566 and PC (2011-12)- 565, PC (2011-12)-569, PC (2011-12)- 573 PC (2011-12)- 590 were identified for NMC and single cane weight, respectively. Clones viz. PC (2011-1 2)-568, PC (2011-12)-571, PC (2011-12)-576 were recommended for cane yield (t/ha).

\section{Introduction}

Sugarcane (Saccharum spp. complex) is an important cash crop and is cultivated in the tropical and subtropical regions of the world. Sugarcane has the distinct characteristic of high sugar concentration accumulated in the stalk. Sugarcane growing countries of the world are lying between the latitude $36.7^{\circ} \mathrm{N}$ and $31.0^{\circ} \mathrm{S}$ of the equator extending from tropical to sub-tropical zones. In India, sugarcane is cultivated all over the country from latitude $80^{\circ} \mathrm{N}$ to $33^{\circ} \mathrm{N}$.

Mahalanobis $\mathrm{D}^{2}$ statistic is a morphometric method and a powerful tool in quantifying the 
degree of divergence at genotypic level. $\mathrm{D}^{2}$ statistic measures the amount of genetic diversity at intra and inter-cluster levels and also determines the relative contribution of each component characters towards the total divergence. Its estimates are free from genetic assumptions and help to identify suitable germplasm for incorporation into plant breeding stocks. Mahalanobis $\mathrm{D}^{2}$ statistic has been mostly used for the selection of parents for crop improvement programme (Arunachalam, 1981). The clusters were made using the $\mathrm{D}^{2}$ values according the Tocher's method (Rao, 1952) and the clustering pattern was determined.

In order to obtain the wide spectrum of variation among the segregants the genotypes belonging to the distant clusters could be incorporated in hybridization program. Keeping the above facts in view, 36 genotypes of Sugarcane were subjected to detailed investigation for the underlined objectives to estimate the extent of genetic diversity among early generation clones of sugarcane based on morphological characterization and to identify donors from diverse group for yield and quality parameters.

\section{Materials and Methods}

The present investigation was carried out to estimate the genetic diversity present among the early generation sugarcane clones on the basis of morphological characterisation and to identify donors from diverse groups for yield and quality parameters. The clones were selected from $\mathrm{C} 1$ generation and were planted as C2 generation at Sugarcane Breeding Block, NEB Crop Research Centre, G.B. Pant University of Agriculture and Technology, Pantnagar, Udham Singh Nagar with early generation clones of Sugarcane. Thirty-three early generation clones (C2) of sugarcane alongwith three checks (CoPant 97222, CoS 8436, CoJ 64) were planted in randomized block design with three replications. Each experimental plot consisted of single row each of 3.50 metres with $90 \mathrm{~cm}$ row to row distance. The observations were recorded for the 10 morphological and juice quality contributing characters viz., Number of Millable Canes (NMC), cane height(m), cane diameter $(\mathrm{cm})$, single cane weight $(\mathrm{Kg})$, juice brix $\%$, juice sucrose $\%$, juice purity $\%$, Commercial Cane Sugar (CCS) \%, cane yield (t/ha), Commercial Cane Sugar (CCS) yield (t/ha).

\section{Statistical Analysis}

The Analysis of variance (ANOVA) was done for randomized block design following the procedure explained by Panes and Sukhatme (1969). The data were analyzed to test the significance of difference between the genotypic mean for various characteristics.

\section{Estimation of variance components}

The phenotypic and genotypic components of variance were calculated using the following formula:

Genotypic variance $\left(\sigma^{2} \mathrm{~g}\right)=\mathrm{MSt}-\mathrm{MSe} / \mathrm{r}$ Phenotypic variance $\left(\sigma^{2} \mathrm{p}\right)=\sigma^{2} \mathrm{~g}+\sigma^{2} \mathrm{e}$

\section{Genetic divergence analysis}

In the present study, genetic divergence among the clones based on all morphological characters was estimated with the help of Mahalonobis $\mathrm{D}^{2}$ statistic (generalized distance) as suggested by Rao (1952).

$D^{2} i j=\sum^{k} t=1(Y i t-Y j t)^{2}$

\section{Group constellation (Clustering pattern)}

Clustering of all the genotypes was done on the method as suggested by Tocher and described by Rao (1952). 


\section{Intra and inter cluster distances}

Using the following formula the intra cluster $\mathrm{D}^{2}$ values were computed:

Intracluster $\mathrm{D}^{2}=\sum \mathrm{Di}^{2} / \mathrm{n}, \mathrm{n}=\mathrm{P}(\mathrm{P}-1) / 2$

Where, $\sum \mathrm{Di}^{2}=$ is the sum of $\mathrm{D}^{2}$ values between all possible combinations (n) of the populations $(\mathrm{P})$ included in a cluster, $\mathrm{n}=$ number of all possible combinations among the populations in a cluster and $\mathrm{P}=$ number of populations included in a cluster.

Inter cluster $\mathrm{D}^{2}=\sum \mathrm{Dij}^{2} /$ ninj

Where, $\sum \mathrm{Dij}^{2}=$ the sum of $\mathrm{D}^{2}$ values between all possible combinations (ninj) of the genotypes included in cluster $\mathrm{i}$ and $\mathrm{j}$ and $\mathrm{ni} \&$ $\mathrm{nj}=$ number of genotypes in cluster $\mathrm{i}$ and $\mathrm{j}$ respectively

\section{Contribution of different clusters towards divergence}

Percent contribution of each character was calculated using the following formula:

Percent contribution of a character $=$ $\frac{\mathrm{N}(\mathrm{X})}{\mathrm{n}(\mathrm{n}-1) / 2} \times 100$

Where, $\mathrm{N}(\mathrm{X})=$ Number of genotypic combinations which were ranked first for the character ' $\mathrm{X}$ ', out of the total genotypic combinations of $n(n-1) / 2$ and $n=$ Number of genotypes.

\section{Results and Discussion}

The analyses of variance indicating the mean sum of squares for all the ten characters studied are presented in the Table 1. F-test revealed highly significant variation among the clones for all the characters studied such as NMC (309.039), cane height (m) (0.2099), cane thickness $(\mathrm{cm})$ (0.187), single cane weight $(\mathrm{Kg})(0.194)$, juice brix \% (5.457), juice sucrose $\%$ (4.473), juice purity \% (1.194), CCS \% (2.199), Cane yield (411.388), CCS yield (5.248).

Based on $\mathrm{D}^{2}$ values estimated, the clustering of the 36 clones was carried out following Tocher's method (Rao, 1952) (Table 2). In all, ten clusters were formed and their composition is given in Table 3 and graphically presented in Fig 1. Cluster I was found to be the largest with 18 genotypes followed by Cluster III with 4 clones, Cluster II and Cluster IV comprising of 3 clones each. Two genotypes each constituted Cluster V and Cluster VI. Rest of the clusters viz., VII, VIII, IX and $\mathrm{X}$ consisted of one clone each.

It was observed that two varieties Co S 8436 and Co J 64 from different locations were falling into one cluster $(\mathrm{V})$ while the progeny clones bred at Pantnagar centre were grouped into different clusters, therefore, It could be inferred from the clustering pattern that genotypes of different geographical areas were constituting one group and also the clones of same geographical areas were grouped into different clusters indicating the independence of geographical diversity and genetic diversity.

On average, most of the clones (50\%) remained in I cluster, while the other clusters comprised only 1 to 4 clones. The high percentage of clones in only one cluster indicates the low level of divergence among the clones. It means that the degree of divergence among the material tested with respect to traits under study was not high.

This may have been due to the narrow genetic base of these clones or the selection pressure put on these clones in previous clonal selection cycles. The selection in sugarcane improvement programs is directed to traits of 
agronomic interest and, in advanced stages, a great number of genotypes has been discarded. So, clones of the $\mathrm{C} 2$ stage are phenotypically much more similar, due to previous selection in early stages that alter the genotypic mean in the desirable direction.

A study of the present data revealed that the intra cluster distance $\left(\mathrm{D}^{2}\right)$ ranged from 0.00 (monogenic cluster) to 6.88 (cluster IV). The maximum intra cluster distance was shown within cluster IV $\left(\mathrm{D}^{2}=6.88\right)$ constituted by 3 clones. The inter cluster distance $\left(\mathrm{D}^{2}\right)$ ranged from 10.64 to 35.44 . The maximum inter cluster distance $\left(D^{2}=35.44\right)$ was observed between cluster IV and VIII. The divergence analysis indicated that promising crosses could be made between progenies allocated in different clusters for high genetic divergence and for favourable morphological traits. The minimum inter cluster distance $\left(\mathrm{D}^{2}\right.$ $=10.64)$ was observed between cluster VII and VIII indicating the low level of genetic diversity between the two and hence are not recommended for the inclusion in the sugarcane breeding programs.

Table.1 Analysis of variance for various yield contributing characters in sugarcane

\begin{tabular}{|c|c|c|c|c|c|c|c|c|}
\hline \multirow{3}{*}{$\begin{array}{l}\text { Source of } \\
\text { variation }\end{array}$} & d.f. & & & & \multicolumn{2}{|c|}{ Mean Square } & \multirow[b]{2}{*}{ Single Cane } & \multirow[b]{2}{*}{ Juice } \\
\hline & & NMC & \multicolumn{2}{|l|}{ Cane } & Cane & & & \\
\hline & & & \multicolumn{2}{|c|}{ height(m) } & \multicolumn{2}{|c|}{ thickness $(\mathrm{cm})$} & weight(kg) & Brix\% \\
\hline Replication & 2 & 13.74 & 0.1385 & & 0.00845 & & 0.05918 & 1.283 \\
\hline Treatment & 35 & $309.039 * *$ & \multicolumn{2}{|c|}{$0.2099 * *$} & $0.1872 * *$ & & $0.1944 * *$ & $5.458 * *$ \\
\hline Error & 70 & 41.086 & 0.0476 & & 0.0374 & & 0.0183 & 0.528 \\
\hline SE(Mean) & 3.701 & & 0.126 & & 0.112 & & 0.0779 & 0.419 \\
\hline CV\% & 11.028 & & 9.124 & & 8.548 & & 11.097 & 4.254 \\
\hline CD at $5 \%$ & 10.438 & & 0.3552 & & 0.3147 & & 0.2199 & 1.184 \\
\hline \multirow{5}{*}{$\begin{array}{l}\text { Source of } \\
\text { variation }\end{array}$} & d.f. & & & & \multicolumn{2}{|c|}{ Mean Square } & & \\
\hline & & & & & & & & \\
\hline & & \multicolumn{2}{|c|}{ Juice sucrose } & \multirow{2}{*}{\multicolumn{2}{|c|}{$\begin{array}{l}\text { Juice } \\
\text { purity\% }\end{array}$}} & CCS\% & \multirow{2}{*}{$\begin{array}{l}\text { Cane } \\
\text { yield }\end{array}$} & \multirow{3}{*}{$\begin{array}{l}\text { CCS } \\
\text { Yield } \\
\text { (t/ha) }\end{array}$} \\
\hline & & $\%$ & & & & & & \\
\hline & & & & & & & $(\mathrm{t} / \mathrm{ha})$ & \\
\hline Replication & 2 & 0.748 & & 1.712 & & 0.317 & 16.562 & 0.1499 \\
\hline Treatment & 35 & $4.473 * *$ & & $1.195 * *$ & & $2.199 * *$ & $411.388^{* *}$ & $5.248^{* *}$ \\
\hline Error & 7( & 0.387 & & 0.541 & & 0.184 & 15.973 & 0.210 \\
\hline SE (Mean) & & 0.359 & & 0.424 & & 0.248 & 2.308 & 0.264 \\
\hline CV\% & & 4.136 & & 0.836 & & 4.139 & 5.728 & 6.344 \\
\hline CD at $5 \%$ & & 1.012 & & 1.197 & & 0.699 & 6.509 & 0.746 \\
\hline
\end{tabular}

**Significant at $1 \%$ level of probability 
Table.2 Clustering patterns of 36 genotypes on the basis of $\mathrm{D}^{2}$ values

\begin{tabular}{|c|c|l|}
$\begin{array}{c}\text { Cluster } \\
\text { No. }\end{array}$ & $\begin{array}{c}\text { No. of } \\
\text { genotypes }\end{array}$ & Genotypes included \\
\hline I & $\mathbf{1 8}$ & PC 2011-12- 559, PC 2011-12- 560, PC 2011-12- 563, PC 2011-12- \\
\hline & & 564, PC 2011-12- 567, PC 2011-12- 572, PC 2011-12- 574, PC \\
\hline & & $2011-12-575$, PC 2011-12- 578, PC 2011-12- 580, PC 2011-12- \\
\hline & & 582, PC 2011-12- 583, PC 2011-12- 584, PC 2011-12- 585, PC \\
\hline & & $2011-12-586$, PC 2011-12- 587, PC 2011-12- 589, PC 2011-12- 591 \\
\hline II & $\mathbf{3}$ & PC 2011-12- 561, PC 2011-12- 562, PC 2011-12- 566 \\
\hline III & $\mathbf{4}$ & PC 2011-12- 565, PC 2011-12- 569, PC 2011-12- 573, PC 2011-12- \\
\hline IV & & 590 \\
\hline V & $\mathbf{3}$ & PC 2011-12- 568, PC 2011-12- 571, PC 2011-12- 576 \\
\hline VI & $\mathbf{2}$ & Co S 8436 and Co J 64 \\
\hline VII & $\mathbf{2}$ & PC 2011-12- 579, PC 2011-12- 581 \\
\hline VIII & $\mathbf{1}$ & PC 2011-12- 570 \\
\hline IX & $\mathbf{1}$ & PC 2011-12- 577 \\
\hline $\mathbf{X}$ & $\mathbf{1}$ & PC 2011-12- 588 \\
\hline
\end{tabular}

Table.3 Average inter and intra-cluster $\mathrm{D}^{2}$ values

\begin{tabular}{|c|c|c|c|c|c|c|c|c|c|c|}
\hline Clusters & I & II & III & IV & V & VI & VII & VIII & IX & $\mathbf{X}$ \\
\hline I & 6.51 & 13.00 & 10.93 & 11.05 & 14.44 & 14.03 & 16.85 & 19.83 & 11.58 & 14.91 \\
\hline II & & 4.18 & 16.11 & 18.72 & 21.62 & 25.36 & 16.12 & 19.78 & 20.06 & 15.71 \\
\hline III & & & 6.13 & 16.73 & 20.86 & 16.51 & 16.00 & 20.87 & 12.49 & 11.33 \\
\hline IV & & & & 6.88 & 16.28 & 20.59 & 22.93 & 35.44 & 20.82 & 20.77 \\
\hline V & & & & & 3.89 & 20.25 & 27.93 & 31.25 & 21.07 & 21.89 \\
\hline VI & & & & & & 4.68 & 28.87 & 31.81 & 25.91 & 16.68 \\
\hline & & & & & & & & & & \\
\hline VII & & & & & & & 0.00 & 10.64 & 24.31 & 19.29 \\
\hline VIII & & & & & & & & 0.00 & 19.96 & 27.68 \\
\hline & & & & & & & & & & \\
\hline IX & & & & & & & & & 0.00 & 24.48 \\
\hline & & . & & & & & & & & \\
\hline $\mathbf{X}$ & & & & & & & & & & 0.00 \\
\hline
\end{tabular}


Table.5 Diverse donors for yield and quality traits in sugarcane identified from present study

\begin{tabular}{|c|c|c|c|}
\hline S. No. & Cane Yield and Quality Characters & Cluster & Donor clones \\
\hline 1 & NMC & II & PC (2011-12)-561, PC (2011-12)-562, PC (2011-12)-566 \\
\hline \multirow[t]{2}{*}{2} & Cane height $(\mathrm{m})$ & VI & PC (2011-12)-579 \\
\hline & & III & PC (2011-12)- 569, PC (2011-12)- 573 \\
\hline \multirow[t]{2}{*}{3} & Cane thickness $(\mathrm{cm})$ & VII & PC (2011-12)-570 \\
\hline & & IV & PC (2011-12)-568, PC (2011-12)-571 \\
\hline 4 & Single cane weight $(\mathrm{Kg})$ & III & PC (2011-12)-565, PC (2011-12)-569, PC (2011-12)-590 \\
\hline \multirow[t]{2}{*}{5} & Juice brix \% & VI & PC (2011-12)-579, PC (2011-12)-581 \\
\hline & & $\mathrm{X}$ & PC (2011-12)-588 \\
\hline \multirow[t]{2}{*}{6} & Juice sucrose\% & VI & PC (2011-12)-581 \\
\hline & & IX & PC (2011-12)-588 \\
\hline \multirow[t]{2}{*}{7} & Juice purity $\%$ & VIII & PC (2011-12)- 577 \\
\hline & & VI & PC (2011-12)-581 \\
\hline \multirow[t]{2}{*}{8} & $\operatorname{CCS} \%$ & VI & PC (2011-12)-581 \\
\hline & & IX & PC (2011-12)-588 \\
\hline \multirow[t]{2}{*}{9} & Cane yield (t/ha) & IV & PC (2011-12)-571 \\
\hline & & VI & PC (2011-12)-581 \\
\hline \multirow[t]{2}{*}{10} & CCS yield (t/ha) & VI & PC (2011-12)-579 \\
\hline & & IV & PC (2011-12)-576 \\
\hline
\end{tabular}


Table.4 Contribution (\%) of each trait towards divergence in sugarcane clones

\begin{tabular}{|r|r|c|}
\hline S. No. & Character & Contribution (\%) \\
\hline $\mathbf{1}$ & No. of millable canes & 13.968 \\
\hline $\mathbf{2}$ & Cane height $(\mathrm{m})$ & 11.587 \\
\hline $\mathbf{3}$ & Cane thickness $(\mathrm{cm})$ & 11.111 \\
\hline $\mathbf{4}$ & Single cane weight $(\mathrm{kg})$ & 6.190 \\
\hline $\mathbf{5}$ & Juice brix percent & 13.650 \\
\hline $\mathbf{6}$ & Juice sucrose percent & 7.619 \\
\hline $\mathbf{7}$ & Juice purity percent & 1.428 \\
\hline $\mathbf{8}$ & CCS percent & 14.92 \\
\hline $\mathbf{9}$ & Cane yield $(\mathrm{t} / \mathrm{h})$ & 7.460 \\
\hline $\mathbf{1 0}$ & CCS yield $(\mathrm{t} / \mathrm{h})$ & 12.063 \\
\hline
\end{tabular}

Fig.1 Cluster diagram showing the intra and inter cluster distances (D)

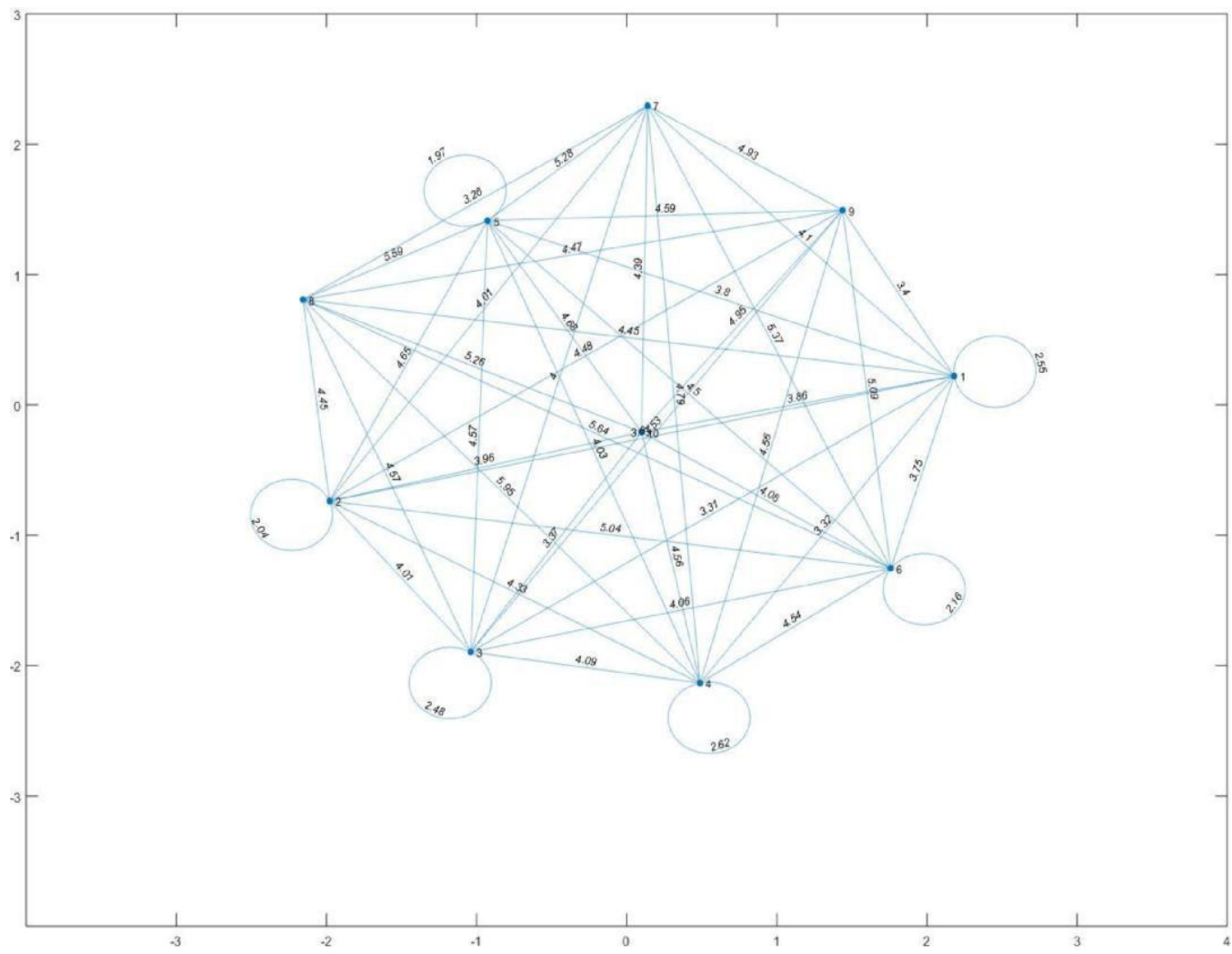


Fig.2 Contribution of each trait towards genetic divergence

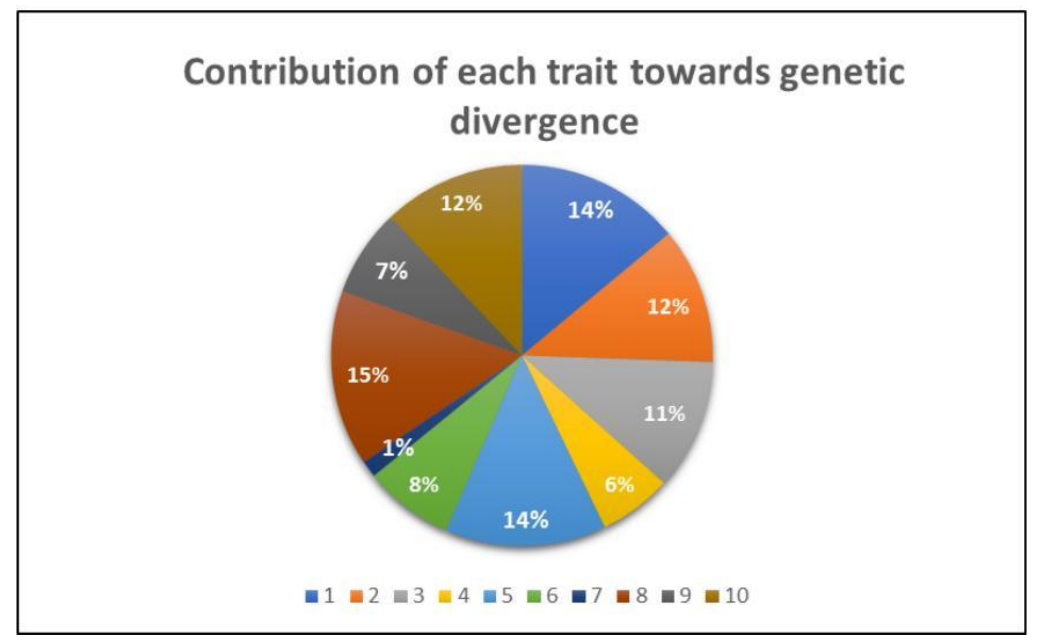

The relative genetic intra and inter cluster distance (D) was calculated by taking square root of D2 values between different clusters (Table 3). The maximum relative genetic distance (D) was found between cluster IV and VIII $(D=5.95$. High or optimum genetic divergence is desired between the parents of hybridization programme for obtaining higher frequency of desirable recombinants. Cluster analysis indicated this experiment material may serve as good source for selecting the diverse parents for hybridization programme aimed at isolating desirable segregants for seed yield and other important characters.

On the basis of cluster mean, cluster VI showed the highest cluster mean for maximum number of cane yield and quality characters among all the clusters indicating the most promising genotypes.

\section{Contribution of different characters towards genetic divergence}

The selection and choice of parents mainly depends upon contribution of characters towards divergence. The relative contribution of each trait towards the expression of genetic divergence was calculated presented in Table 4 and Figure 2.
The highest contribution in manifestation of genetic divergence was exhibited by CCS \% (14.92), followed by number of millable canes $(13.97 \%)$, Juice brix percent $(13.65 \%)$, CCS yield (12.06\%), Cane height (11.587\%), Cane thickness (11.11\%), Juice sucrose percent $(7.62 \%)$ and Cane yield (7.46\%). Lowest contribution was made by juice purity percent $(1.428 \%)$ followed by single cane weight $(6.190 \%)$.

\section{Identification of genetically diverse sugarcane donors for different traits}

The present investigation indicated that clones PC (2011-12)-579, PC (2011-12)-581 and PC (2011-12)-588 constituting the cluster VI and cluster IX respectively, were superior for most of the cane yield and quality contributing characters viz. cane height $(\mathrm{m})$, juice brix percent, juice sucrose percent, juice purity percent, cane yield (t/ha), CCS percent and CCS yield (t/ha) (Table 5). Clones PC (2011-12)-561, PC (2011-12)-562, PC (201112)-566 (cluster II) and PC (2011-12)-569, PC (2011-12)-573 (cluster III) were identified promising for NMC and cane height (m) respectively. Clones of cluster IV viz. PC (2011-12)-568, PC (2011-12)-571 were recommended for cane thickness $(\mathrm{cm})$ and PC 
(2011-12)-576 for cane yield ( $\mathrm{t} / \mathrm{ha}) . P C$ (201112)- 565, PC (2011-12)- 569, PC (2011-12)573, PC (2011-12)- 590 (cluster III) were identified for single cane weight $(\mathrm{Kg})$. PC (2011-12)-565 was identified for juice sucrose $\%, \mathrm{CCS} \%$, and CCS yield (t/ha). The clones exhibiting higher mean values for the various characters could be utilized in the improvement of these characters in the comprehensive breeding programmes.

\section{References}

Arunachalam, V. 1981. Genetic distance in plant breeding. Indian Journal of Genetics and Plant Breeding, 41(2):226-236.

Da Silva J. A. and Bressiani J.A. 2005. Sucrose synthase molecular marker associated with sugar content in elite sugarcane progeny. Genetics and Molecular Biology, 28: 294-298.

Guruprasad, H., Nagaraja, T. E., Uma, M. S., Patel, V. N. and Anand, M. 2015. Character Association and Path Analysis for Cane and Sugar Yield in Selected Clones of Sugarcane (Saccharum officinarum L.). Trends in Biosciences, 8(6):1466-1469.

Panse, V.G., and Sukhatme, P.V. 1969. Statistical method for Agricultural
Workers-Published by Indian Council of Agricultural Research, New Delhi, 381pp.

Punia, M. S., Choudhary, B. S. and Hooda, R. S. 1983. Genetic divergence in sugarcane. Indian Journal of Genetics and Plant Breeding, 53: 434-436.

Rao, C.R. 1952. "Advanced Statistical Methods in Biometrical Research", John Willy and Sons, Inc., New York, 390pp.

Singh, R. K. and Chaudhary, B. D. 1977. Biometrical methods in quantitative genetic analysis. Kalyani Publishers, New Delhi. 318 p.

Singh, R.B., and Bains, S.S. 1968. Genetic divergence for ginning outtern and its component in upland cotton (Gossypium hirsutum L.) varieties obtained from different geographical locations. Indian Journal of Genetics and Plant Breeding, 26: 262-268.

Spencer, G. L., and Meade, G. P. 1955. Cane Sugar Hand Book. J. Wiley and Sons, New York.

Tahir, M., Rahman, H., Gul, R., Ali, A., and Khalid, M. 2013. Genetic Divergence in Sugarcane Genotypes. American Journal of Experimental Agriculture, 3(1): 102-109.

\section{How to cite this article:}

Neetu, Anand Singh Jeena, Anil Kumar Bairwa, Deepak Koujalagi, Surendra Pal Singh and Usha Pant. 2018. Genetic Diversity Analysis of Sugarcane (Saccharum spp. Complex) based on Morphological Characterisation Using Mahalanobis $\mathrm{D}^{2}$. Int.J.Curr.Microbiol.App.Sci. 7(08): 4355-4363. doi: https://doi.org/10.20546/ijcmas.2018.708.457 